\title{
BOOK REVIEWS.
}

\author{
Modern Trends in Paediatrics, by Sir Leonard G. Parsons, M.D., F.R.S.,
} F.R.C.P. Pp. 546. Price 55/-. London: Butterworth \& Co. I.td. 19.50.

This book is the latest addition to the Modern Trends Series. Each chapter deals with a separate subject written by an acknowledged authority in his field. Most of the writers are British but there are also articles by Australian, Canadian, Swedish, American and Dutch paediatricians and other experts. The subject chosen have been the sources of considerable advances in knowledge in recent years, or have received increasing study because of their importance in the field of child health, e.g., neonatal and infant mortality statistics, nutrition, ete.

It must be difficult for an editor to achieve a consistent standard in a book written by many authors but in this book the articles are, with a few exceptions, of an extremely high standard. Worthy of particular mention for their excellence, in the reviewer's opinion, are the chapters on Stillbirths and Congenital Malformations following Rubella and other virus diseases during pregnancy by Dods of Australia ; Haemolytic Disease of the Newborn by Allott; Congenital Heart Disease by Keith of Toronto; The Normal Development of the Infant by Illingworth ; Viral Diseases by Sabin of Cincinnati; Poliomyelitis by Sir James Spence; and the Endocrine Glands by Crooke.

There is an interesting account of Recent Trends in the U.K. in Preventive Paediatric Services by W. S. Craig. The Place of Child Health Institutes in Medical Education and Research is discussed by Professor Alan Moncrieff. The reviewer feels that he must record his opinion that this account does not give an altogether consistent and objective report of the place accorded to paediatric teaching and research in the various British Medical Schools. Nobody would contest Professor Moncrieff's plea that the student should be given more instruction than he has received in the past in preventive or social paediatrics. None the less, the total time devoted to the study of paediatrics in the British medical curriculum is still but a very small part of the six years' course. Important as the study of preventive paediatrics may be it is, in the reviewer's opinion, even more essential that the undergraduate student be not allowed to go out into general practice until he has been thoroughly grounded in the art of eliciting and interpreting the signs of disease as they appear in the young child. The present enthusiasm for social paediatrics must not be allowed to make teachers less aware of the undergraduate's need for training in diagnostic and curative paediatrics; because at the present time and for a long time to come the general practitioner will usually first see a child because he is ill and in need of accurate diagnosis and treatment. 'This aspect of the student's training receives little attention in Professor Moncrieff's article. Although the reviewer has been provoked to criticise one chapter, it is not a bad thing in a book that it should thus provoke criticism and discussion especially among those who can influence the future development of paediatrics in this country.

As the late Sir Leonard Parsons pointed out in his Preface, the study of child health and disease in the U.K. has advanced in the last few years from a rather insignificant and neglected section of medicine to become one of the major subjects in the medical curriculum. This book reflects how fruitful has been this increased interest in paediatrics and it proves the justification for further expansion in undergraduate and postgraduate teaching. Nobody who is concerned with any aspect of child care can but be intensely interested in and stimulated by the various articles. In addition the book is beautifully turned out and contains many fine photographs. It is worthy of a place in the library of every paediatrician, child welfare doctor and general practitioner, and it should be read by everybody who is concerned with the planning of the medical curriculum or with the administration of our national child care services. 